Vol. 3, Issue I, pp. 46-59, 2021

Available online at: https://tljbm.org/jurnal/index.php/tljbm

\title{
The Impact of Tourism Destination Image on Tourist Behavioral Intention through Tourist Satisfaction: Evidence from the Ramelau Mountain, Timor-Leste
}

\author{
Remígia Maria Jerônimo Viana, Estanislau de Sousa Saldanha, Domingos M.B. Barreto \\ Graduate School-MBA Program, Dili Institute of Technology, Dili, Timor-Leste. \\ Email:fmiziaviana@gmail.com,estanislausaldanha@yahoo.com,domingosmb.barreto@gmail.com
}

\begin{abstract}
The objectives of the research are to investigate the influence of destination image and tourist satisfaction on tourist behavioral intention, and to test the mediation effect of tourist satisfaction on the relationship between destination image and tourist behavioral intention. Using accidental sampling method, 400 tourists visited Ramelau Mountain participated in the survey by filling up the prepared questionnaires. While Smart-PLS 3.1 was used for data analysis. The result of the research demonstrates that tourist destination image and tourist satisfaction positively and significantly influences tourist behavioral intention, and tourist satisfaction significantly influences the relationship between destination image and behavioral intention. Empirically the research helps enrich studies on tourist destinations with tourist behavioral intention in countries that just start developing their tourism industry. This study also assists the government in developing natural attractions, culture, infrastructure, facility, accessibility, value, and price to change tourist behavioral intention to visit and revisit, and to recommend tourist destinations to other people.
\end{abstract}

Keywords: Tourist Destination, Tourist Destination Image, Tourist Satisfaction, Tourist Behavioral Intention.

\section{Introduction}

The tourism sector contributes immensely to the global economy (Lopes, 2012) because the sector generates activities that provide large incomes to the government, as well as creates jobs for people. For this reason, the government of many countries seeks to improve their service and develop tourism potential as tourist destination to attract tourist to visit (Chen \& Tsai, 2007; Meng \& Cui, 2020; Singh, 2020). Tourists visit a tourist destination based on their vision (cognitive), feeling (affective), and action (conative) (Ceylan et al., 2020; Herle, 2018) or perception, representation, mentality, and various impressions between reality and image (Al-Gasawneh \& AlAdamat, 2020). Therefore behavioral intention will continues to drive tourist behavior in the future (Ajzen 2012) because behavior intention influenced by antecedent behavior (Perugini \& Bagozzi, 2001; Tucker et al., 2019), which in turn lead to triggers person's behavior (Oliver \& Swan, 1989) to take any future actions (Banki et al., 2014).

Various empirical studies have demonstrated that tourist destination image influences behavioral intention to revisit a tourist destination (Afshardoost \& Eshaghi, 2020; Çelik \& Dedeoğlu, 2019; Choe \& Kim, 2018; Dedeoğlu, 2019; Su et al., 2020). However, numerous studies also show that tourist destination image is not adequate to attract tourist's behavioral intention to revisit (Aziz et al., 2015; Chen \& Tsai, 2007; Seetanah et al., 2020).

Tourists often utilize marketing process to choose a tourist destination (Alcocer \& Ruiz, 2019; Framke, 2002; Lewis \& Jönsson, 2016), and this is certainly based on service quality, satisfaction, and attraction (Chen \& Tsai, 2007).

Tourist satisfaction is the joyful experience of tourists after visiting a tourist destination. Or positive feelings of tourists during the visit to a destination which in turns lead to stimulate tourist behavioral intention (Lu et al., 2020). Quality tourist trips enhance tourist satisfaction and create positive behavioral intention to take decision to revisit the same destination (Bigné et al., 2001; Saini \& Arasanmi, 2020). Previous empirical studies also confirmed that tourist destination image directly influences satisfaction which in turns leading to influence tourist behavioral intention (Saini \& Arasanmi, 2020; Toudert \& Bringas-Rábago, 2019; Viet et al., 2020).

Tourist satisfaction and behavioral intention serves as important indicators for a successful tourist destination (Huang et al., 2015) because it links to the relationship between tourist destination image and behavioral intention (Afshardoost \& Eshaghi, 2020). In general, tourists satisfy with a destination which can provide proper rest, safety assurance, cultural attraction, shopping sites, good environment, and easy access (Ruiz et al., 2018).

Therefore, recent studies continually explore possible elements to attract tourists to visit a tourist destination. However, these studies are hugely carried out in wellestablished tourist destinations, and lack of focus on emergent tourist destinations, particularly in linking tourist destination, satisfaction and behaviour intention. Therefore, this study aims to fulfill the lack of studies in this field. The specific aims of this research are: (1) to test and explain the influence of tourist destination image and tourist satisfaction on tourist behavioral intention at the tourist destination of Ramelau Mountain, Ainaro Municipality and (2) to test and explain the mediation effect of tourist satisfaction on the relationship between tourist destination image and tourist behavioral intention at Ramelau Mountain, Ainaro Municipality. 


\section{Theoretical Framework, Research Model and Hypothesis}

\section{1. Tourist Destination}

A tourist destination is a place that can offer tourism products such as the attraction of natural resources, human resources and tourism support facilities (Framke, 2002; Chan \& Marafa, 2018) which attract tourists to visit and see (Feldmane et al., 2015). The term of tourist destination have been explained by previous authors with various business concepts (Framke, 2002; Grauslund, 2013). Tourist destination refers to a country, state, region, city, or villa that conducts business to attract tourist to visit (Alcocer \& Ruiz, 2019; Herle, 2018). Tourist destination is also defined based on the management approach (product and firm metaphor) (Gurtner, 2009), system, and networking (Zemła, 2016). Tourist destinations consist of tangible and intangible elements (Qu et al., 2011; RamseookMunhurrun et al., 2015). Tangible elements refer to natural attractions such as beaches, mountains and cultural heritage, while intangible element refers to culture, custom, and history (Manhas et al., 2016). A tourist destination is a package of facilities and services that consist of multidimensional attributes that determine tourist attraction when selecting their travel $(\mathrm{Hu}$ \& Ritchie, 1993).

\section{2. Tourist Destination Image}

Tourist destination image always changes (Gartner, 1986; Echtner \& Ritchie, 1991; Gallarza, 2002; Kim \& Morrsion, 2005; Chen et al., 2014) in accord to natural dynamic changes. Therefore, it requires good marketing for enhancing image of a tourist destination (Gallarza, 2002). Tourist destination image has attracted researchers since 1970 (Chen et al., 2014). Gunn in 1992 started conducting a research (Viet et al., 2020) on how a destination can attract potential tourists (Saini \& Arasanmi, 2020) because destination image affects or influences tourist behaviors (Jenkins, 1999; Erawan, 2019; Ceylan et al., 2020; Afshardoost \& Eshaghi, 2020). The term tourist destination image has unclear definition (Echtner \& Ritchie, 1993; Jenkins, 1999; Loi et al., 2017; Al-Gasawneh \& Al-Adamat, 2020; Viet et al., 2020), which represents individual mentality on their understanding, belief, feeling, and total perception of a tourist destination (Baloglu \& McCleary, 1999; Crompton, 1979). Destination image is also defined as a subjective interpretation of perception, impression, and mental representation (Bigné et al., 2001; Aksoy \& Kiyci, 2011). The image is a totally cognitive structure associated with a concept in a person's mind (Tall \& Vinner, 1981). To be a success in a tourism market, a tourist destination always undertakes evaluation and creates a new image (Tilaki et al., 2016). A good image can serve as a positive advantage for a good tourist destination which can pass on to potential tourists (Alcocer \& Ruiz, 2019).

The attribute of tourist destination image consists of three elements i.e., cognitive, affective, and conative (Afshardoost \& Eshaghi, 2020; Stylidis et al., 2017; Stylos et al., 2016; Viet et al., 2020). The cognitive attribute provides a vision that gives rise to belief and expression reflected from the assessment of image (Afshardoost \& Eshaghi, 2020; Stylidis et al., 2017; Stylos et al., 2016; Viet et al., 2020). The affective attribute is how the expression of sentiment on destination image (Papadimitriou et al., 2013). Conative attributes consist of action from a tourist that has the intention to revisit a tourist destination and recommend it to potential tourists (Agapito et al., 2013; Gartner, 1994).

Indicators of the tourist destination image are attraction (natural, goods produced, artificial construction, heritage, special events), accessibility (transportation system, terminals, vehicles, amenities (accommodation, eating facilities, shopping, and other tourist destination), activities (all activities that can be done during a visit to tourist destination), supporting service (bank, telecommunication, postal service, news agency, hospital, etc.) (Buhalis, 2000; Wang \& Hsu, 2010; Mohamad et al., 2011; Soteriades, 2012; Basaran, 2016; Roy et al., 2016; Chan, 2018).

\section{3. Tourist Satisfaction}

Satisfaction has various interpretations which looks at cognitive and emotion (Ragab et al., 2019). Satisfaction represents a person's pleasure or unhappiness as a result of comparing a product (Herle, 2018). Hence, tourist satisfaction is a reaction or decision of a tourist based on his/her emotion and cognition (Bigné et al., 2001). When it has met the needs and level of consumption of each person it results in satisfaction (Oliver, 1999). Quality, price (value) expectation is antecedent factors for satisfaction (Shahrivar, 2012). Satisfaction is merely a prediction of an attitude (Bigné et al., 2001). Tourist satisfaction depends on a tourist's culture and country of origin (Kozak \& Rimmington, 2000). Also depends on a socioeconomic, demographic, and behavioral indicator such as age, gender, ethnicity, education, occupation, marital status, income (Huh, 2002; Shahrivar, 2012). Accommodation, foods, tourist service, event, tourist attraction, tourism activity, shopping, environment, and access to a destination are indicators of tourist satisfaction (Chi \& Qu, 2008; Mai et al., 2019). Therefore, tourist satisfaction is positive experienced by the tourist after visiting a tourist destination (Wang, 2016; Prayag et al., 2017).

Tourist satisfaction is an important success indicator for business performance, sustainability of tourism management, and hospitality management, hence it becomes a reference for creating and developing a good tourist destination image (Gnanapala, 2015; Maghsoodi Tilaki et al., 2016; Ranjanthran \& Mohammed, 2010). This will guaranty tourists to revisit and recommend to other potential tourists (Alcocer \& Ruiz, 2019).

Tourists make a subjective judgment on their satisfaction based on the attribute of a tourist destination performance and information on a tourist destination (Sohn et al., 2016). The attribute of a positive tourist destination image generates satisfaction (Biswas et al., 2020). Therefore, the positive and negative attribute is important for assessing the experience of tourist's visits (Yoon \& Uysal, 2005). 


\section{4. Tourist Behavioural Intention}

Behavioral intention is used to truly understand tourist behavior or motivation in the future (Afshardoost \& Eshaghi, 2020). Tourist behavioral intention has three types i.e., (1) the intention of tourist to visit, (2) the intention of tourist to revisit, and (3) intention of tourist to recommend (Zeithaml et al., 1996; Bigné et al., 2001; Lee et al., 2005; Chen \& Tsai, 2007; Wang $\&$ Hsu, 2010; Papadimitriou et al., 2013; Sohn et al., 2016). The intention to visit is a tourist behavioral intention that exists before a tourist takes a trip and is influenced by tourist destination image (Hosany et al., 2020). The intention to revisit is tourists repeat their actions where they want to revisit a tourist destination that has been visited before (Viet et al., 2020). The experience of visiting a tourist destination triggers an opinion or a decision from a tourist (Perugini \& Bagozzi, 2004). Hence when a tourist has a positive perception on a tourist destination then the tourist will also have a positive tourist behavior (Sohn et al., 2016).

The concept of tourist behavioral intention is considered as a tourist intention to revisit and pass positive information to other tourists on a tourist destination through word of mouth (WOM) (Chen \& Funk, 2010; Wang \& Hsu, 2010; Singh, 2020). WOM influences tourist perception (Herle, 2018). Good satisfaction also generates a positive effect in WOM (Hsu et al., 2020).

The key elements of tourist intention to revisit a tourist destination are the natural environment, reputation, hospitality of the community (Prayag, 2012; Carvache-Franco et al., 2020) and products from a tourist destination (Pranić et al., 2013). Tourist behavioral intention (conative loyalty) serves as a good indicator of tourist satisfaction (Sohn et al., 2016). Pre-visit and post-visit favorable indicators in tourist behavioral intention are connected to the intention to revisit a tourist destination (Loi et al., 2017).

\section{5. Conceptual Framework and Research Model}

Studies have proved the relationship between destination image and tourist satisfaction (Alcocer \& Ruiz, 2019; Bigné et al., 2001), while there are lack of studies on destination image impact on behavioural intention; therefore, tourist satisfaction is used as intervening variable for the relationship between destination image and behavioural intentions.

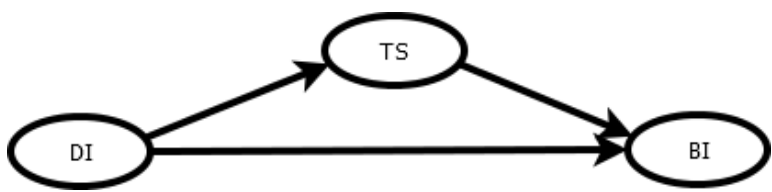

Figure 1. Research conceptual framework (DI = destination image; $\mathrm{TS}=$ Tourist satisfaction; $\mathrm{BI}=$ tourist behavior intention).

\section{6. Hypothesis}

\subsubsection{Tourist Destination Image and Tourist Behavioural} Intention

Image is an accumulation of beliefs, ideas, impressions that a person has on a tourist destination from time to time (Crompton, 1979; Baloglu \& Gartner, 1994; McCleary, 1999; Leisen, 2001). Since the nature of a tourist image formation is always dynamic (Ghazali \& Cai, 2013) which comes from cognitive, affective, and conative elements (Afshardoost \& Eshaghi, 2020; Ceylan et al., 2020; Herle, 2018). When a factor that forms an image changes, but the change does not affect an image, whether it is positive and negative changes (Fakeye \& Crompton, 1991). Factor or dimension, attribute and items that serve as indictors of destination image are explored in various literatures referred above such as natural attraction, climate, accommodation, entertainment, foods, infrastructure, etc. (Basaran, 2016). These factors become pull and push factors that affect tourist behavioral intention (Preko et al., 2019). Previous research demonstrates that tourist destination image does have a significant impact on tourist behavioral intention (Afshardoost \& Eshaghi, 2020; Basaran, 2016; Phucharoen et al., 2016; Ragab et al., 2019). With the factor of tourist destination image that influences behavioral intention, the following hypothesis (1) is derived.

H1: Tourist destination image influence positively and significantly on tourist behavioral intention.

\subsubsection{Tourist Destination Image and Tourist Satisfaction}

Tourists will satisfy with what they see since it affects what he/she feels which results in positive or negative satisfaction (Basaran, 2016). Tourist satisfaction has generated after they visit a tourist destination (Wang \& Hsu, 2010), of which it can be influenced by price, quality, and prior expectation (Anderson et al., 1994; Shahrivar, 2012). Tourist satisfies with what they feel about tourism products such as tourism attraction, accommodation, accessibility to tourist destination, support services, and amenities (Tukamushaba et al., 2016). Tourist destination image has a positive and significant influence on satisfaction (Chen et al., 2017; Hasan et al., 2019; Loi et al., 2017; Ragab et al., 2019). Tourist is satisfied with the product that comes from destination image; hence the following hypothesis (2) is derived.

$\mathrm{H} 2$ : Tourist destination image has a positive and significant influence on tourist satisfaction.

\subsubsection{Tourist Satisfaction and Behavioural Intention}

Tourist satisfaction is a reaction or decision based on tourist emotion and cognition (Bigné et al., 2020). High-level tourist satisfaction can further increase the intention to revisit a tourist destination (Chen \& Tsai, 2007; Chi \& Qu, 2008; del Bosque \& San Martín, 2008; Lee et al., 2005). Studies revealed that satisfaction is direct antecedent of behavioral intention (Mohamad et al., 2011) which lead to enhance behaviour 
intention to revisit and recommend to the other tourists by using mouth to mouth promotion (Banki et al., 2014; Sohn et al., 2016; Chan, 2018; Ragab et al., 2019; Singh, 2020). A tourist will revisit when it satisfies with the visit, hence hypothesis (3) is derived as below

H3: Tourist satisfaction has a positive and significant impact on tourist behavioral intention.

\subsubsection{Tourist Destination Image and Tourist Satisfaction and Behavioral Intention}

Tourist destination image has an impact on tourist satisfaction and behavioral intention (Hasan et al., 2019; Toudert \& Bringas-Rábago, 2019). Tourist destination image generates prediction on revisit intention through tourist satisfaction (Loi et al., 2017; Hasan et al., 2019). Therefore, this research generates the following hypothesis.

H4: Tourist destination image through tourist satisfaction influence positively and significantly on tourist behavioral intention.

\section{Research Method}

\subsection{Research Population and Sample}

This research was conducted in the tourism destination of Ramelau Mountain of sub-district Hatubuilico of Ainaro Municipality, Timor-Leste in 2021. Since visitor data has not been collected, hence the research population is infinite (Bigné et al., 2001; del Bosque \& San Martín, 2008). This research applies nonprobability sampling to identify population and sample. Respondents are limited only to age 16 and above. Demographic information such as age, gender, occupation, level of education was incorporated into a questionnaire (Herle, 2018; Taherdoost, 2018).

\subsection{Data Collection and instrument}

Data was collected by using questionnaire which is adapted from the previous empirical studies (Wang \& Hsu, 2010; Banki et al., 2014; Basaran, 2016; Ragab et al., 2019). Tourist destination has six (6) dimensions namely natural attraction (4 items), cultural attraction (6 items), social adjustment and environment (5 items), infrastructure and facility (4 items), accessibility (4 items), price and value (3 items) (Basaran, 2016); tourist satisfaction (6 items), and behaviour intention (6 items) (Wang \& Hsu, 2010; Banki et al., 2014; Chan, 2018; Ragab et al., 2019).

The research used a five Likert attitude scale-extensively ranging from 1 (strongly disagree) to 5 (strongly agree) (Bertan \& Altintaş, 2013).

Questionnaires were distributed to respondents in Dili and in Ramelau Mountain, Ainaro Municipality based on accidental sampling method. The respondents are identified as those who have visited to Ramelau Mountain in the last three years.

\subsection{Data Analysis}

This research is a quantitative research in order to explore respondents' perceptions on Ramelau Mountain as tourist destination. To undertake the test, the path model was drawn based on previous theoretical and empirical foundation on tourist destination image, satisfaction and behaviour intention. A statistic computer package namely Smart-PLS 3.0 was used to test validity and reliability of the model following the path recommendation of Hair et al. (2014) and Hair et al. (2017).

When reliability and indicator validity are concluded, the next step is to test the hypothesis using path coefficient. In PLS, significant relations can be met if the $T$ values are above the minimum threshold value of 1.96 , and the P-values are below than the maximum allowable value 0.05 (Hair et al., 2014; Hair et al., 2017; Khan et al., 2019).

\section{Findings and Discussion \\ 4.1.Demographic Characteristics of Respondents}

The total number of respondents for the research is 400 , of whom male $(55.5 \%)$ and female $(45.5 \%)$, while youth $(64.6 \%)$ and adults $(35.5 \%)$. Based on education level, respondents with University Degree (57.8\%), Secondary School (28.5\%), Master Degree (9\%), Ph.D. (2\%), Primary School (1.3\%), and never attending school (1.5\%). The majority of the visitors is students $(46.5 \%)$, and is then followed by public servants $(25.3 \%)$, private sector staff $(17.8 \%)$, and unemployment (10.4\%). In terms of the visiting intention to Ramelau Mountain, religious pilgrimage $(36.5 \%)$, adventure $(29 \%)$, see natural landscape $(27.8 \%)$, and historic reasons $(6.8 \%)$, with the lengthy of visit time from one day (56\%), two days (36\%), and three days (8\%).

\subsection{Validity and Reliability Tests}

There are two types of validity tests: Convergent Validity and Discriminant Validity. The convergent validity test is normally used the outer loading (OL) and the average variance extracted (AVE) (Hair et al., 2014; Jr. et al., 2017). The items are valued if OL values are above the threshold value of 0.7 . The items with OL values below than 0.5 were considered invalid because it influences the content validity of model (AVE), therefore these items have to be eliminated from the model (Hair et al., 2014). To this, some items in this model have to be eliminated as their OL values are lower than 0.5. These items are DI11, DI21, DI22, DI23, and DI52 (see Figure 2 below). Figure 2 shows that the OL values of the items are well above the explorative threshold values of 0.6 , and therefore, it can be used to test the inner model (Hair et al., 2014). 
Vol. 3, Issue I, pp. 46-59, 2021

Available online at: https://tljbm.org/jurnal/index.php/tljbm

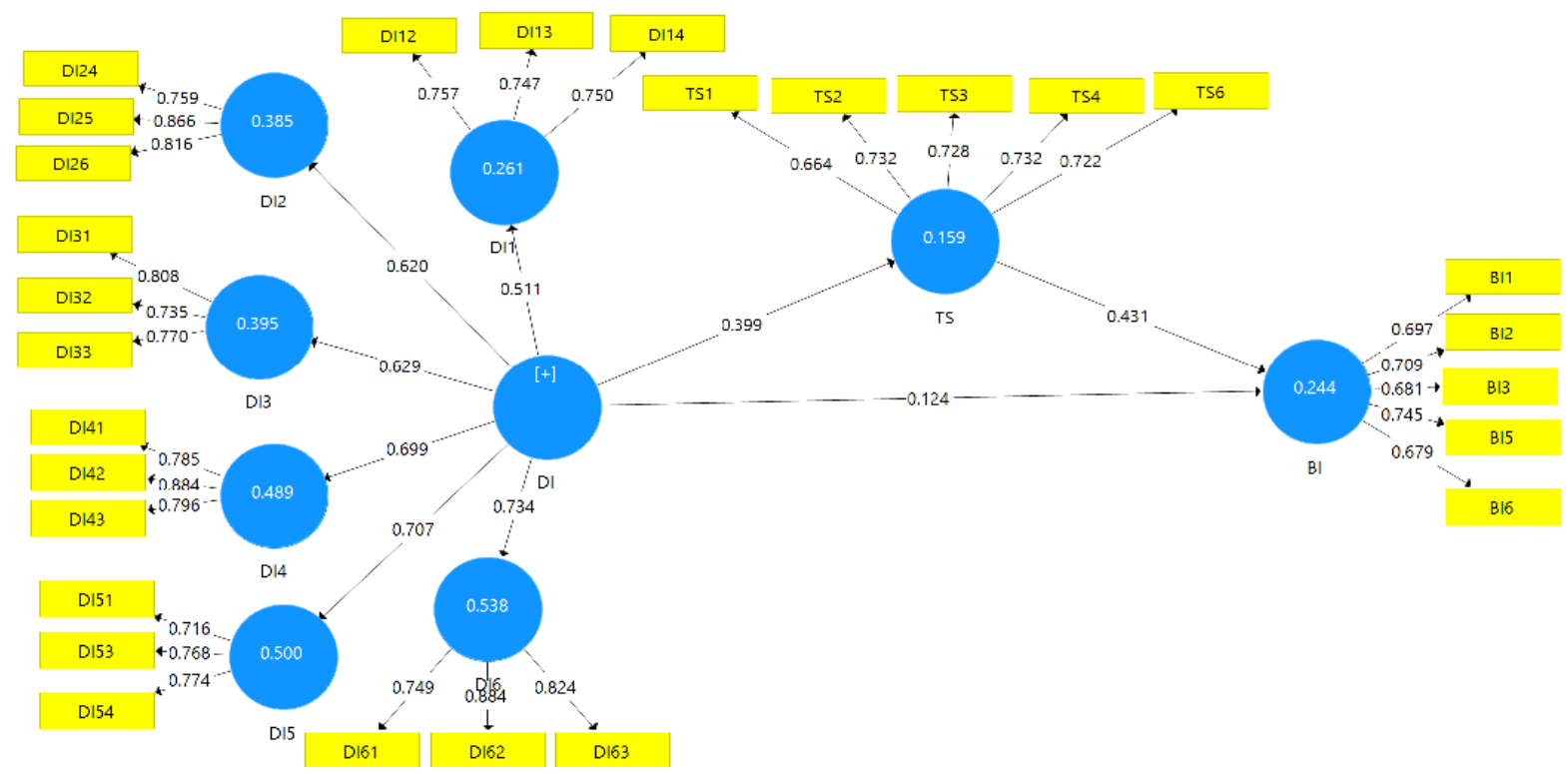

Figure 2. Outer Loading (OL) for Convergent Validity

Another convergent validity is AVE with the minimum threshold value is greater than 0.5 (Hair et al., 2014). Table III shows AVE values of all items are well above 0.5 , which means that all items are valid to test inner model.
Discriminant Validity used two parameters namely FornellLarcker criterion (Fornell \& Lacker, 1981) and HeterotraitMonotrait Ratio (HTMT). FL criterion method states that the construct shares more variance with its indicators than with any other construct.

Table I. Fornell Larcker Criterion for Discriminant Validity

\begin{tabular}{cccccccccc}
\hline Item & BI & DI & DI1 & DI2 & DI3 & DI4 & DI5 & DI6 & TS \\
\hline BI & 0.703 & & & & & & & & \\
DI & 0.297 & & & & & & & & \\
DI1 & 0.230 & 0.511 & 0.751 & & & & & & \\
DI2 & 0.120 & 0.620 & 0.326 & 0.815 & & & & & \\
DI3 & 0.173 & 0.629 & 0.367 & 0.208 & 0.771 & & & \\
DI4 & 0.149 & 0.699 & 0.165 & 0.352 & 0.278 & 0.823 & & \\
DI5 & 0.194 & 0.707 & 0.121 & 0.307 & 0.328 & 0.494 & 0.753 & & \\
DI6 & 0.222 & 0.734 & 0.125 & 0.374 & 0.280 & 0.461 & 0.480 & 0,821 & \\
TS & 0.481 & 0.399 & 0.334 & 0.138 & 0.355 & 0.152 & 0.177 & 0,330 & 0,716 \\
\hline
\end{tabular}

To test this requirement, the AVE of each construct should be higher than the highest squared correlation with any other construct (Hair et al., 2014). As seen from the Fornell-Larcker criterion, all items are valid to use for inner model test (Table I). As indicated, by using the Heterotrait-Monotrait Ratio (HTMT) parameters (Henseler et al., 2015), all items are valid (Table II).
The study also conducts a reliability test to ensure all items have good internal consistency. The test for internal validity uses Cronbach Alpha (CA) and composite reliability (CR). Items are reliable if the CA and CR values are greater than 0.7 , in exception to the explorative research, which allows the CA and CR values are acceptable at the minimum of 0.6. (Hair et al., 2014 and Hair et al., 2017). Table III demonstrates that the values of CA and CR of all items are exceeded 0.6, which means that all items are reliably used for inner model test. 
Table II. Heterotrait-Monotrait Ratio for Discriminant Validity

\begin{tabular}{cccccccc}
\hline Item & BI & DI1 & DI2 & DI3 & DI4 & DI5 & DI6 \\
\hline DI1 & 0.328 & & & & & & \\
DI2 & 0.187 & 0.476 & & & & & \\
DI3 & 0.237 & 0.559 & 0.265 & & & & \\
DI4 & 0.205 & 0.237 & 0.462 & 0.370 & & & \\
DI5 & 0.314 & 0.313 & 0.445 & 0.456 & 0.704 & & \\
DI6 & 0.303 & 0.181 & 0.498 & 0.364 & 0.604 & 0.715 & \\
TS & 0617 & 0486 & 0183 & 0489 & 0.198 & 0.253 & 0.436 \\
\hline
\end{tabular}

Table III. Validity (AVE) and Reliability (CA and CR)

\begin{tabular}{cccc}
\hline Item & $\begin{array}{c}\text { Cronbach's } \\
\text { Alpha } \\
\text { (CA) }\end{array}$ & $\begin{array}{c}\text { Composite } \\
\text { Reliability } \\
\text { (CR) }\end{array}$ & $\begin{array}{c}\text { Average } \\
\text { Variance } \\
\text { Extracted (AVE) }\end{array}$ \\
\hline BI & 0.746 & 0.830 & 0.594 \\
DI1 & 0.615 & 0.796 & 0.565 \\
DI2 & 0.745 & 0.855 & 0.664 \\
DI3 & 0.670 & 0.815 & 0.595 \\
DI4 & 0.760 & 0.862 & 0.677 \\
DI5 & 0.622 & 0.797 & 0.567 \\
DI6 & 0.755 & 0.860 & 0.674 \\
TS & 0.762 & 0.840 & 0.512 \\
\hline
\end{tabular}

\subsection{Inner Model Test R-Values}

The inner model analysis is used to test relations among variables. In this research, the parameter used is the value of $\mathrm{R}$ Square $\left(\mathrm{R}^{2}\right)$. R-Square is used to know the strength of relations among variables in this model.

Table IV. R Square Values

\begin{tabular}{ccc}
\hline Item & R Square & R Square Adjusted \\
\hline BI & 0.244 & 0.241 \\
DI1 & 0.261 & 0.259 \\
DI2 & 0.385 & 0.383 \\
DI3 & 0.395 & 0.394 \\
DI4 & 0.489 & 0.488 \\
DI5 & 0.500 & 0.499 \\
DI6 & 0.538 & 0.537 \\
TS & 0.159 & 0.157 \\
\hline
\end{tabular}

It can also be used to understand the prediction capacity within the model. The value of R-Square is ranged from 0.75 (strong), 0.50 (moderate), and 0.25 (weak) (Hair et al., 2014). Table IV shows the value of the dependent variable (BI) of the R-Square in the model which reaches 0.244. Thus, the relationship between variables in the research model is weak, implicating the prediction capacity of variables in the model to attain up to $24.4 \%$. The remaining can be predicted from other variables that are not included in this model.

\subsection{Hypothesis Testing}

This research has four hypotheses that intend to test the direct effect between variables using SMART-PLS 3.0. Parameters used to evaluate them are path coefficients ( $\mathrm{T}$ and $\mathrm{P}$ values). The significant influence of two variables can be accepted if the $\mathrm{T}$ value is greater than 1.96 and the $\mathrm{P}$ value is less than 0.05 (Hair et al., 2014 and Hair et al., 2017).

The first hypothesis is to test the influence of tourist destination images on tourist behavioral intentions. The results of the hypothesis test, as shown in Table $\mathrm{V}$, is that the value of $\mathrm{T}$ (2.252) which is greater than the minimum threshold value of 1.96 , and $P$ value $(0.025)$, which is less than 0.05 . This means that tourist destination image positively and significantly influences tourist behavioral intentions. Thus, hypothesis $\mathrm{H} 1$ is supported.

The second hypothesis is to test the influence of tourist destination images on tourist satisfaction at Ramelau Mountain. The results of the study demonstrate that the $T$ value (6.878) is greater than the 1.96 , and the $\mathrm{P}$ value $(0.000)$, which is less than the maximum allowable value of 0.05 (Table V). This means that tourist destination image (DIT) positively and significantly influence tourist satisfaction (TS). Therefore, the $\mathrm{H} 2$ is supported.

The third hypothesis is to test the influence of tourist satisfaction (TS) on the tourist behavioral intentions (BI) at Ramelau Mountain. The results of the test show that the $\mathrm{T}$ value (7.981) is greater than 1.96 , and the $P$ value $(0.000)$ is less than 0.05 (Table V). This shows that tourist satisfaction positively and significantly influences the tourist behavioral intentions at Ramelau Mountain. Hence, the H3 can be accepted. 
Table V. T and P Values for Hypothesis Test (Direct Effect)

\begin{tabular}{ccccccc}
\hline & $\begin{array}{c}\text { Original } \\
\text { Sample } \\
(\mathbf{O})\end{array}$ & $\begin{array}{c}\text { Sample } \\
\text { Mean } \\
(\mathbf{M})\end{array}$ & $\begin{array}{c}\text { Standard } \\
\text { Deviation } \\
(\text { STDEV })\end{array}$ & $\begin{array}{c}\text { T Statistics } \\
(\mid \mathbf{O} / \text { STDEV|) }\end{array}$ & P Values & Note \\
\hline DI -> BI & 0.124 & 0.131 & 0.055 & 2.252 & 0.025 & Significant \\
DI -> TS & 0.399 & 0.413 & 0.058 & 6.878 & 0.000 & Significant \\
TS -> BI & 0.431 & 0.434 & 0.054 & 7.941 & 0.000 & Significant \\
\hline
\end{tabular}

The fourth hypothesis is to test the mediation effect of tourist satisfaction on the relationship between tourist destination image and tourist behavioral intentions at Ramelau Mountain. The result of the specific indirect test or mediation test shows that the $\mathrm{T}$ value (4.704) is greater than 1.96 , and the $\mathrm{P}$ value
$(0.000)$ is less than 0.05 (Table VI). This means that tourist satisfaction has a significant effect on the relationship between tourist image destinations and tourist behavioral intentions. Therefore, the H4 is supported.

Table VI. Mediation Effects (Specific Indirect Effects)

\begin{tabular}{|c|c|c|c|c|c|c|}
\hline & $\begin{array}{c}\text { Original } \\
\text { Sample (O) }\end{array}$ & $\begin{array}{c}\text { Sample } \\
\text { Mean (M) }\end{array}$ & $\begin{array}{c}\text { Standard Deviation } \\
(\text { STDEV) }\end{array}$ & $\begin{array}{c}\text { T Statistics } \\
(\mid \mathbf{O} / \text { STDEV } \mid)\end{array}$ & $\begin{array}{c}\text { P } \\
\text { Values }\end{array}$ & Note \\
\hline DI -> TS -> BI & 0.172 & 0.180 & 0.037 & 4.704 & $\mathbf{0 . 0 0 0}$ & Significant \\
\hline
\end{tabular}

\section{Discussion}

The first objective of the current study is to examine the influence of tourist destination image on the tourist behavioral intentions at the Ramelau Mountain tourist destination. The findings of the study show that tourist destinations positively and significantly affect tourist behavioral intentions. This means that when a tourist image destination is good the tourist behaviour intentions increase to visit and revisit the Ramelau Mountain as a tourist destination. The natural, cultural attractions, as well as social adjustment to culture, price, infrastructure, facility, and accessibility may help to attract tourists and recommending to their friends, sharing positive feedbacks to other potential visitors to visit and/or revisit the Ramelau Mountain. The findings also show that tourists destination factors that highly influence the tourist behavioral intentions are price (D6), accessibility (D5), infrastructure and facilities (D4) in comparison with Natural attraction (D1), cultural attraction (D2) as well as social and cultural adjustments (D3) (Figure 3). The findings of the research confirm the previous studies that show destination image influence behavioral intentions (Afshardoost \& Eshaghi, 2020; Çelik \& Dedeoğlu, 2019; Choe \& Kim, 2018; Dedeoğlu, 2019; $\mathrm{Su}$ et al., 2020; Viet et al., 2020) because good tourist destination image can create positive, happy impressions and therefore tourists can recommend the destination to others and possibly to revisit in the future. However, the findings of the research are asymmetric with other studies which show that even negative tourist destination image may still stimulate tourists to visit and revisit ( $\mathrm{Li}$ et al., 2018). For instance, the Chinese tourists may still want to revisit North Korea because they want to experience challenges, geographical, cultural, and political proximities.
The second objective of the study is to test the influence of tourist destination image on tourist satisfaction. The findings show that the tourist destination image has a positive and significant influence on tourist satisfaction. This means that tourist destination images reflected by accessibility, infrastructure, natural and attraction facilities, as well as cultural and environmental adjustments and price are highly influential on the positive feelings of tourists to visit the Ramelau Mountain. In this case, good accessibility, infrastructure, natural and cultural attractions, as well as cultural and environmental adjustments will contribute to tourist's happiness in Ramelau Mountain and vice versa. Good service quality and tourist attraction go in line with the tourist expectation (Chen \& Tsai, 2007). Tourist destination image influences significantly on tourist satisfaction due to accessibility and infrastructure, good facilities, and price, which lead to enhance tourist happiness to give positive feedback, and revisit the Ramelau Mountain as a tourist destination. Numerous authors have revealed that quality of accessibility, infrastructure, facility, and price will form good tourist destination image, thus attracting tourists to visit a tourist destination (Reza Jalilvand et al., 2012; Arnegger \& Herz, 2016; Tan, 2017; Dedeoğlu, 2019). The current study confirms the results of the previous studies revealed that destination images influence significantly on tourist satisfaction (Aziz et al., 2015; Toudert \& Bringas-Rábago, 2019; and Saini \& Arasanmi, 2020).

The third objective of the study is to test the influence of tourist satisfaction on the tourist behavioral intention at the Ramelau Mountain tourist destination. The findings show that tourist satisfaction has a positive and significant influence on the tourist behavioral intentions at the tourist destination. If a tourist is satisfied with a tourist destination will also increase the behavioral intention of tourists to visit a tourist destination and vice versa. 


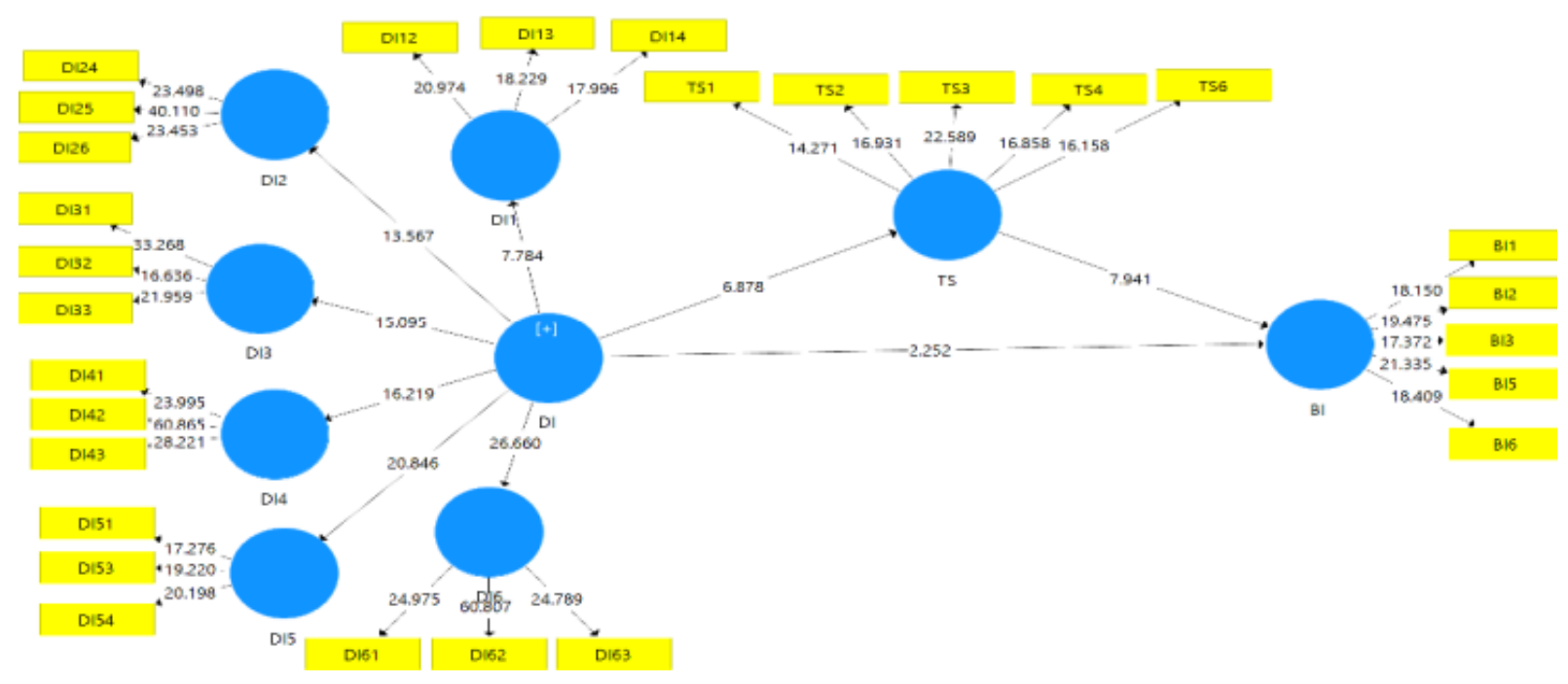

Figure 3. Path Coefficient

Tourists are satisfied once their expectations are met in a tourist destination, which lead them to decide to revisit or recommend to the other tourists to visit the same tourist destinations (Akgün et al., 2020). The findings also indicate that factors push tourists to visit Ramelau Mountain tourist destination are accessibility, infrastructure, facility, and affordable price. These factors are regarded as supporting factors that offer comfortability to tourists to visit a tourist destination (Tavitiyaman et al., 2021). The findings confirm the previous studies that tourist satisfaction influences tourist behavioral intentions (Aziz et al., 2015; Toudert \& Bringas-Rábago, 2019; Saini \& Arasanmi, 2020; Seetanah et al., 2020).

Finally, the fourth objective of the study is to test mediation effects of tourist satisfaction on the relationship between tourist destination image and tourist behavioral intentions at the Ramelau Mountain tourist destination. The findings of the study show that tourist satisfaction positively influences the relationship between tourist destination image and tourist behavioral intentions. The satisfied tourists will form tourism positive feelings which in turns enhancing their intention to visit and revisit a tourist destination. This confirms that tourist destination image which is reflected from natural and cultural attractions, affordable price, accessible site, good infrastructure, facilities will stimulate tourists to have positive feelings, and decide to visit and revisit and promote a tourist destination via word of mouth information (Toudert \& Bringas-Rábago, 2019; Saini \& Arasanmi, 2020).

\section{Conclusions and Implication}

The objectives of the research are to test and analyze the influence of tourist destination image and tourist satisfaction on tourist behavioral intentions at Ramelau Mountain as a tourist destination in Timor-Leste, as well to test the mediation effect of tourist satisfaction on the relationship between destination image and behaviour intention. From the findings, some significant conclusions can be drawn from this study: (1) Tourist destination image positively and significantly influences the tourist behavioral intention. A good tourist destination images will attract more tourists to visit. Accessibility, price, and values, infrastructure, and facilities, natural cultural originality, culture and belief will attract more tourists than those that have artificial and modern nature. (2) Tourist destination images also positively and significantly influence the tourist satisfaction. Good tourist destination image will possibly increase the level of tourist satisfaction which is dictated by good accessibility, price, infrastructure, and facilities. (3) Client satisfaction has a positive and significant influence on the tourist behavioral intentions. A satisfied tourist will lead to visit and visit Ramelau Mountain, as well as recommend the destination to the other families and friends to visit the same tourism destination. (4) Client satisfaction has a significant effect on the relationship between tourist destination image and tourist behavioral intentions. Tourist satisfaction will help in promoting the tourist destination image of Ramelau Mountain, thus implicating that more tourists will come to visit and revisit the tourist destination, as well as recommending it to others to come and visit.

\section{Limitation and Future Research}

The findings of the research show that tourist destination image has a positive and significant influence on the tourist behavioral intentions of Ramelau Mountain in Ainaro Municipality. However, there are some limitations of the current study to be improved to increase the number of tourists visiting the destination.

1) The study limits itself to observing the influence of variables of tourist destination image and tourist satisfaction on tourist behavioral intentions at the Ramelau Mountain. Hence, future studies should focus more on the internal and external factors related to service provision at the Ramelau Mountain destination to increase the number of tourists visiting the tourist destination. This is justified in the research by showing 
Vol. 3, Issue I, pp. 46-59, 2021

Available online at: https://tljbm.org/jurnal/index.php/tljbm

variables that can predict the dependent variables such as tourist behavioral intentions whose R2 value is very small (24.4\%).

2) The study only uses a questionnaire to collect data. Future studies should also employ mixed methods to pull data in-depth, hence socially acceptable responses can be avoided.

3) Tourist destination image has a positive and significant influence on the tourist behavioral intentions in visiting Ramelau Mountain as a tourist destination. This means that the government and local communities need to develop the tourist destination to improve the image of the tourist destination in attracting more tourists visiting it. Important factors to consider are improved infrastructure and facilities to ensure accessibility and comfortability of the tourists. It is also equally important to ensure that the Ramelau Mountain tourist destination is wellcared in its original nature and to ensure that the price is affordable for them.

4) Client satisfaction is a deciding factor in stimulating tourist behavioral intention to visit Ramelau Mountain as a tourist destination in Timor-Leste. This means that the government and local communities need to improve the facilities such as road, transport, accommodation, services, restaurants, and souvenir shops to offer comfortability and increase the good image of the Ramelau Mountain as a tourist destination to attract more domestic and international tourists visiting the Ramelau Mountain as a tourist destination in Timor-Leste.

\section{References}

Afshardoost, M., \& Eshaghi, M. S. (2020). Destination image and tourist behavioural intentions: A meta-analysis. Tourism Management, 81 .

Agapito, D., Oom do Valle, P., \& da Costa Mendes, J. (2013). The Cognitive-Affective-Conative Model of Destination Image: A Confirmatory Analysis. Journal of Travel and Tourism Marketing, 30(5), 471-481.

Ajzen, I. (2012). The theory of planned behavior. Handbook of Theories of Social Psychology: Volume 1, July, 438-459.

Akgün, A. E., Senturk, H. A., Keskin, H., \& Onal, I. (2020). The relationships among nostalgic emotion, destination images and tourist behaviors: An empirical study of Istanbul. In Journal of Destination Marketing and Management (Vol. 16).

Aksoy, R., \& Kiyci, Ş. (2011). A destination image as a type of image and measuring destination image in tourism (Amasra Case). European Journal of Social Sciences, 20(3), 478-488.

Al-Gasawneh, J. A., \& Al-Adamat, A. M. (2020). The relationship between perceived destination image, social media interaction and travel intentions relating to Neom City. Academy of Strategic Management Journal, 19(2), 1-12.

Alcocer, N. H., \& Ruiz, V. R. L. (2019). The role of destination image in tourist satisfaction: the case of a heritage site. Economic Research-Ekonomska Istrazivanja, 0(0), 1-18.

Anderson, E. W., Fornell, C., \& Lehmann, D. R. (1994). Customer
Satisfaction, Market Share, and Profitability: Findings from Sweden. Journal of Marketing, 58(3), 53.

Arnegger, J., \& Herz, M. (2016). Economic and destination image impacts of mega-events in emerging tourist destinations. In Journal of Destination Marketing and Management (Vol. 5, Issue 2, pp. 76$85)$.

Aziz, A., Yusof, R. M., Ayob, M., Bakar, N. T. A., \& Awang, A. H. (2015). Measuring Tourist Behavioural Intention Through Quality in Malaysian Medical Tourism Industry. Procedia Economics and Finance, 31, 280-285.

Baker, D. A., \& Crompton, J. L. (2000). Quality, satisfaction and behavioral intentions. Annals of Tourism Research, 27(3), 785804.

Baloglu, S., \& McCleary, K. W. (1999). A model of destination image formation. Annals of Tourism Research, 26(4), 868-897.

Banki, M. B., Ismail, H. N., Dalil, M., \& Kawu, A. (2014). Moderating role of affective destination image on the relationship between tourists satisfaction and behavioural intention: Evidence from Obudu mountain resort. Journal of Environment and Earth Science, 4(4), 47-60.

Basaran, U. (2016). Examining the Relationships of Cognitive, Affective, and Conative Destination Image: A Research on Safranbolu, Turkey. International Business Research, 9(5), 164.

Bertan, S., \& Altintaş, V. (2013). Visitors' perception of a tourism destination: The case of Pamukkale. Tourismos, 8(1), 115-132.

Bevanda, V., Štetić, S., Pavić, L., Pažek, K., \& Pavlovič, M. (2018). Agritourism. Between Agriculture and Tourism. a Review. 3rd International Thematic Monograph - Thematic Proceedings: Modern Management Tools and Economy of Tourism Sector in Present Era, January, 243-257.

Bigné, J. E., Sánchez, M. I., \& Sánchez, J. (2001). Tourism image, evaluation variables and after purchase behaviour: interrelationship. Tourism Management, 22(6), 607-616.

Biswas, C., Deb, S. K., Hasan, A. A.-T., \& Khandakar, M. S. A. (2020). Mediating effect of tourists' emotional involvement on the relationship between destination attributes and tourist satisfaction. Journal of Hospitality and Tourism Insights, ahead-of-p(ahead-ofprint).

Carvache-Franco, W., Carvache-Franco, M., Carvache-Franco, O., \& Hernández-Lara, A. B. (2020). Motivation and segmentation of the demand for coastal and marine destinations. Tourism Management Perspectives, 34(September 2019), 100661

Çelik, S., \& Dedeoğlu, B. B. (2019). Psychological factors affecting the behavioral intention of the tourist visiting Southeastern Anatolia. Journal of Hospitality and Tourism Insights, 2(4), 425450.

Ceylan, D., Cizel, B., \& Karakas, H. (2020). Cross-nationality importance performance analysis of Middle East all-inclusive mass 
tourism destination image. Journal of Hospitality and Tourism Insights, ahead-of-p(ahead-of-print).

Chan, C. S., \& Marafa, L. M. (2018). Branding places and tourist destinations: A conceptualisation and review. In The Branding of Tourist Destinations: Theoretical and Empirical Insights (pp. 1542). Emerald Publising Limited.

Chan, S. (2018). Factors Affecting Revisit Intention With Customer Satisfaction As a Mediating Variable in Eco Friendly Resorts. Jurnal Manajemen Inovasi, 9(1), 1-13.

Chen, C. F., \& Tsai, D. C. (2007). How destination image and evaluative factors affect behavioral intentions? Tourism Management, 28(4), 1115-1122.

Chen, J. V., Htaik, S., Hiele, T. M. B., \& Chen, C. (2017). Investigating International Tourists' Intention to Revisit Myanmar Based on Need Gratification, Flow Experience and Perceived Risk. Journal of Quality Assurance in Hospitality and Tourism, 18(1), 25-44.

Chen, N., \& Funk, D. C. (2010). Exploring destination image, experience and revisit intention: A comparison of sport and nonsport tourist perceptions. Journal of Sport and Tourism, 15(3), 239259.

Chen, N., Ji, S., \& Funk, D. C. (2014). An extended study on destination image decay of sport tourists over time. Journal of Destination Marketing and Management, 2(4), 241-252.

Chi, C. G. Q., \& Qu, H. (2008). Examining the structural relationships of destination image, tourist satisfaction and destination loyalty: An integrated approach. Tourism Management, 29(4), 624-636.

Choe, J. Y. (Jacey), \& Kim, S. (Sam). (2018). Effects of tourists' local food consumption value on attitude, food destination image, and behavioral intention. International Journal of Hospitality Management, 71, 1-10.

Cruz Ruiz, E., Bermúdez González, G., \& Tous Zamora, D. (2018). Destination image, satisfaction and destination loyalty in cruise tourism: the case of Málaga (Spain). Tourism \& Management Studies, 14(1), 58-68.

Dedeoğlu, B. B. (2019). Shaping tourists' destination quality perception and loyalty through destination country image: The importance of involvement and perceived value. In Tourism Management Perspectives (Vol. 29, pp. 105-117).

del Bosque, I. R., \& San Martín, H. (2008). Tourist satisfaction a cognitive-affective model. Annals of Tourism Research, 35(2), $551-573$

Echtner, C. M., \& Ritchie, J. R. B. (1993). The Measurement of Destination Image: An Empirical Assessment. Journal of Travel Research, 3-13.

Echtner, C., \& Ritchie, J. (1991). The meaning and measurement of destination image. Journal of Tourism Studies, 2(2), 2-12.
Erawan, T. (2019). India's destination image and loyalty perception in Thailand. International Journal of Tourism Cities, 6(3), 565-582.

Fakeye, P. C., \& Crompton, J. L. (1991). Image Differences between Prospective, First-Time, and Repeat Visitors to the Lower Rio Grande Valley. Journal of Travel Research, 30(2), 10-16.

Feldmane, Z., Miguel, P., \& Ferreira, R. (2015). Projected and erceived Image of Latvia as a Tourist Destination. October.

Fornell, \& Lacker. (1981). Discriminant Validity Assessment : Use of Fornell \& Larcker criterion versus HTMT Criterion Discriminant Validity Assessment: Use of Fornell \& Larcker criterion versus HTMT Criterion. Journal of Physics: Conference Series PAPER, 01263(890), 6.

Framke, W. (2002). The destination as a concept: A discussion of the business-related perspective versus the socio-cultural approach in tourism theory. Scandinavian Journal of Hospitality and Tourism, 2(2), 92-108.

Gallarza, M. G. . I. G. S. H. C. G. (2002). Destination Image Towards a Conceptual Framework. Anal Tourism Research, 29(1), $56-78$.

Gartner, W. C. (1986). Temporal influences on image change. Annals of Tourism Research, 13(4), 635-644.

Gartner, W. C. (1994). Image Formation process. Journal of Travel \& Tourism Marketing, February, 1994.

Ghazali, R. M., \& Cai, L. (2013). Social media sites in destination image formation. In Tourism Social Science Series (Vol. 18, pp. 73-86).

Gnanapala, W. K. A. (2015). Tourists Perception and Satisfaction: Implications for Destination Management MBA-FGS View project Tourists Perception and Satisfaction: Implications for Destination Management. American Journal of Marketing Research, 1(1), 7-19.

Grauslund, D. (2013). Tourism Destinations - From Geographical Areas to Dynamic Movements. Journal of Chemical Information and Modeling, 53(9), 1689-1699.

Gurtner, Y. (2009). Tourism Crisis: Management and Recovery in Tourist-Reliant Destinations. In Communities Living With Hazards (pp. 82-101).

Hair, J. F., Ringle, C. M., \& Sarstedt, M. (2011). PLS-SEM: Indeed a silver bullet. Journal of Marketing Theory and Practice, 19(2), 139-152.

Hair Jr., J. F., Matthews, L. M., Matthews, R. L., \& Sarstedt, M. (2017). PLS-SEM or CB-SEM: updated guidelines on which method to use. International Journal of Multivariate Data Analysis, 1(2), 107.

Hasan, M. K., Abdullah, S. K., Lew, T. Y., \& Islam, M. F. (2019). The antecedents of tourist attitudes to revisit and revisit intentions for coastal tourism. International Journal of Culture, Tourism, and 
Hospitality Research, 13(2), 218-234.

Henseler, J., Ringle, C. M., \& Sarstedt, M. (2015). A new criterion for assessing discriminant validity in variance-based structural equation modeling. Journal of the Academy of Marketing Science, 43(1), 115-135.

Herle, F.-A. (2018). The Impact of Destination Image on Tourists' Satisfaction and Loyalty in the Context of Domestic Tourism. Marketing - from Information to Decision Journal, 1(2), 14-26.

Hosany, S., Buzova, D., \& Sanz-Blas, S. (2020). The Influence of Place Attachment, Ad-Evoked Positive Affect, and Motivation on Intention to Visit: Imagination Proclivity as a Moderator. Journal of Travel Research, 59(3), 477-495.

Hsu, C. L., Pan, Y. J., Yan, Q. W., \& Yan, M. R. (2020). Key factors influencing word-of-mouth intentions: the case of college freshmen in Taiwan. Measuring Business Excellence.

Hu, Y., \& Ritchie, J. R. B. (1993). Measuring Destination Attractiveness : A Contextual Approach. 2(34), 25-34.

Huang, H., Lunhua Mao, L., Wang, J., \& Zhang, J. J. (2015). Assessing the relationships between image congruence, tourist satisfaction and intention to revisit in marathon tourism: the Shanghai International Marathon. International Journal of Sports Marketing and Sponsorship, 16(4), 46-66.

Huh, J. (2002). Tourist Satisfaction with Cultural and Heritages Site : The Virginia Historic Triangle. Culture.

Isaac, R. K., \& Çakmak, E. (2014). Understanding visitor's motivation at sites of death and disaster: The case of former transit camp Westerbork, the Netherlands. Current Issues in Tourism, 17(2), 164-179.

Jenkins, O. H. (1999). Understanding and measuring tourist destination images. International Journal of Tourism Research, $1(1), 1-15$

Jiang, Y. (2013). Diversify the Destination Image of Las Vegas to Chinese Market. University of Nevada, Las Vegas.

John L. Crompton. (1979). An Assessment of the Image of Mexico as a Vacation Destination and the influence of geographical location upon that image. Journal of Travel Research, 1(Spring), $18-23$.

Khan, G. F., Sarstedt, M., Shiau, W. L., Hair, J. F., Ringle, C. M., \& Fritze, M. P. (2019). Methodological research on partial least squares structural equation modeling (PLS-SEM): An analysis based on social network approaches. Internet Research, 29(3), 407429.

Kim, B., Kim, S., \& King, B. (2019). Religious tourism studies: evolution, progress, and future prospects. Tourism Recreation Research, 45(2), 185-203.

Kim, H. K., \& Lee, T. J. (2018). Brand equity of a tourist destination. Sustainability (Switzerland), 10(2), 1-21.
Kim, S. S., \& Morrsion, A. M. (2005). Change of images of South Korea among foreign tourists after the 2002 FIFA World Cup. Tourism Management, 26(2), 233-247.

Kineses, Á., Tóth, G., Tömöri, M., \& Michalkó, G. (2017). Characteristics of transit tourism in Hungary with a focus on expenditure. Regional Statistics, 6(2), 129-148.

Korstanje, M. E. (2020). The Dark Tourist: Consuming Dark Spaces in the Periphery. In Tourism, Terrorism and Security (pp. 135-150).

Kozak, M., Crotts, J. C., \& Law, R. (2007). The impact of the perception of risk on international travellers. International Journal of Tourism Research, 9(4), 233-242.

Kozak, M., \& Rimmington, M. (2000). Tourist satisfaction with Mallorca, Spain, as an off-season holiday destination. Journal of Travel Research, 38(3), 260-269.

Lee, C. K., Lee, Y. K., \& Lee, B. K. (2005). Korea's destination image formed by the 2002 World Cup. Annals of Tourism Research, 32(4), 839-858.

Lee, Y. J. (2016). The Relationships Amongst Emotional Experience, Cognition, and Behavioural Intention in Battlefield Tourism. Asia Pacific Journal of Tourism Research, 21(6), 697715.

Leisen, B. (2001). Image segmentation: The case of a tourism destination. Journal of Services Marketing, 15(1), 49-66.

Lewis, C. C., \& Jönsson, C. H. (2016). Promotion Tools Used in the Marketing of Sport Tourism Experiences in a Mature Tourism Destination. The Handbook of Managing and Marketing Tourism Experiences, 397-407.

Loi, L. T. I., So, A. S. I., Lo, I. S., \& Fong, L. H. N. (2017). Does the quality of tourist shuttles influence revisit intention through destination image and satisfaction? The case of Macao. In Journal of Hospitality and Tourism Management (Vol. 32, pp. 115-123).

Lopes, S. D. F. (2012). Post hoc segmentation combining conjoint analysis and a two-stage cluster analysis. African Journal of Business Management, 6(1).

Lu, C. S., Weng, H. K., Chen, S. Y., Chiu, C. W., Ma, H. Y., Mak, K. W., \& Yeung, T. C. (2020). How port aesthetics affect destination image, tourist satisfaction and tourist loyalty? Maritime Business Review, 5(2), 211-228.

Maghsoodi Tilaki, M. J., Hedayati Marzbali, M., Abdullah, A., \& Bahauddin, A. (2016). Examining the Influence of International Tourists' Destination Image and Satisfaction on Their Behavioral Intention in Penang, Malaysia. Journal of Quality Assurance in Hospitality and Tourism, 17(4), 425-452.

Mai, K. N., Nguyen, P. N. D., \& Nguyen, P. T. M. (2019). International tourists' loyalty to Ho Chi Minh City destination-a mediation analysis of perceived service quality and perceived 
value. Sustainability (Switzerland), 11(19).

Manhas, P. S., Manrai, L. A., \& Manrai, A. K. (2016). Role of tourist destination development in building its brand image: A conceptual model. Journal of Economics, Finance and Administrative Science, 21(40), 25-29.

Meng, B., \& Cui, M. (2020). The role of co-creation experience in forming tourists' revisit intention to home-based accommodation: Extending the theory of planned behavior. Tourism Management Perspectives, 33, 100581.

Mitchell, V., Henthorne, T. L., \& George, B. (2020). Making Sense of Dark Tourism: Typologies, Motivations and Future Development of Theory. In Tourism, Terrorism and Security (pp. 103-114).

Mohamad, M., Ali, A. M., \& Ghani, N. I. A. (2011). a Structural Model of Destination Image, Tourists' Satisfaction and Destination Loyalty. International Journal of Business and Management Studies, 3(2), 167-177.

Murphy, P., Pritchard, M. P. ., \& Smith, B. (2000). The destination product and its impact on traveller perceptions. Tourism Management, 21(1), 43-52.

Oliver, R. L. (1999). Whence Consumer Loyalty? 25th Russian Particle Accelerator Conference, RuPAC 2016, 63(1999), 33-44.

Oliver, R. L., \& Swan, J. E. (1989). Consumer Perceptions of Interpersonal Equity and Satisfaction in Transactions: A Field Survey Approach. Journal of Marketing, 53(2), 21-35.

Papadimitriou, D., Apostolopoulou, A., \& Kaplanidou, K. (Kiki). (2013). Destination Personality, Affective Image, and Behavioral Intentions in Domestic Urban Tourism. Journal of Travel Research, 54(3), 302-315.

Perugini, M., \& Bagozzi, R. P. (2001). The role of desires and anticipated emotions in goal-directed behaviours: Broadening and deepening the theory of planned behaviour. British Journal of Social Psychology, 40(1), 79-98.

Perugini, M., \& Bagozzi, R. P. (2004). The distinction between desires and intentions. European Journal of Social Psychology, 34(1), 69-84.

Pham, H. S. T., \& Khanh, C. N. T. (2020). Ecotourism intention: the roles of environmental concern, time perspective and destination image. Tourism Review.

Phucharoen, P., Sriboonlue, U., \& Assarut, N. (2016). The effects of destination image, destination personality and self- congruity on tourists' intention. International Journal of Applied Business and Economic Research, 14(13), 8991-9007.

Pranić, L., Marušić, Z., \& Sever, I. (2013). Cruise passengers' experiences in coastal destinations - Floating "B\&Bs" vs. floating "resorts": A case of Croatia. Ocean and Coastal Management, 84, $1-12$.
Prayag, G. (2012). Paradise for who? Segmenting visitors' satisfaction with cognitive image and predicting behavioural loyalty. International Journal of Tourism Research, 14(1), 1-15.

Prayag, G., Hosany, S., Muskat, B., \& Del Chiappa, G. (2017). Understanding the Relationships between Tourists' Emotional Experiences, Perceived Overall Image, Satisfaction, and Intention to Recommend. Journal of Travel Research, 56(1), 41-54.

Prebensen, N. K. (2007). Exploring tourists' images of a distant destination. Tourism Management, 28(3), 747-756.

Preko, A., Doe, F., \& Dadzie, S. A. (2019). The future of youth tourism in Ghana: motives, satisfaction and behavioural intentions. Journal of Tourism Futures, 5(1), 5-21.

Qu, H., Kim, L. H., \& Im, H. H. (2011). A model of destination branding: Integrating the concepts of the branding and destination image. Tourism Management, 32(3), 465-476.

Ragab, H., Mahrous, A. A., \& Ghoneim, A. (2019). Egypt's perceived destination image and its impact on tourist's future behavioural intentions. International Journal of Tourism Cities, 6(2), 449-466.

Ramseook-Munhurrun, P., Seebaluck, V. N., \& Naidoo, P. (2015). Examining the Structural Relationships of Destination Image, Perceived Value, Tourist Satisfaction and Loyalty: Case of Mauritius. In Procedia - Social and Behavioral Sciences (Vol. 175, pp. 252-259).

Ranjanthran, M., \& Mohammed, B. (2010). Domestic Tourism : Perception of domestic tourist on tourism products in Penang Island. 795-816.

Reza Jalilvand, M., Samiei, N., Dini, B., \& Yaghoubi Manzari, P. (2012). Examining the structural relationships of electronic word of mouth, destination image, tourist attitude toward destination and travel intention: An integrated approach. In Journal of Destination Marketing and Management (Vol. 1, Issues 1-2, pp. 134-143).

Saini, S., \& Arasanmi, C. N. (2020). Attaining digital advocacy behaviour through destination image and satisfaction. International Journal of Tourism Cities, August.

Sarstedt, M., Ringle, C. M., Henseler, J., \& Hair, J. F. (2014). On the Emancipation of PLS-SEM: A Commentary on Rigdon (2012). Long Range Planning, 47(3), 154-160.

Sarstedt, M., Ringle, C. M., Smith, D., Reams, R., \& Hair, J. F. (2014). Partial least squares structural equation modeling (PLSSEM): A useful tool for family business researchers. Journal of Family Business Strategy, 5(1), 105-115.

Seetanah, B., Teeroovengadum, V., \& Nunkoo, R. (2020). Destination Satisfaction and Revisit Intention of Tourists: Does the Quality of Airport Services Matter? Journal of Hospitality and Tourism Research, 44(1), 134-148.

Shahrivar, R. B. (2012). Factors That Influence Tourist Satisfaction. Journal of Travel and Tourism Research, Special, 61- 
79.

Singh, B. E. B. A. (2020). Modeling domestic tourism_ motivations, satisfaction and tourist behavioral intentions.pdf. Heliyon.

Sohn, H. K., Lee, T. J., \& Yoon, Y. S. (2016). Relationship between Perceived Risk, Evaluation, Satisfaction, and Behavioral Intention: A Case of Local-Festival Visitors. Journal of Travel and Tourism Marketing, 33(1), 28-45.

Stylidis, D., Shani, A., \& Belhassen, Y. (2017). Testing an integrated destination image model across residents and tourists. In Tourism Management (Vol. 58, pp. 184-195).

Stylos, N., Vassiliadis, C. A., Bellou, V., \& Andronikidis, A. (2016). Destination images, holistic images and personal normative beliefs: Predictors of intention to revisit a destination. Tourism Management, 53, 40-60.

Su, L., Lian, Q., \& Huang, Y. (2020). How do tourists' attribution of destination social responsibility motives impact trust and intention to visit? The moderating role of destination reputation. In Tourism Management (Vol. 77).

Taherdoost, H. (2018). Sampling Methods in Research Methodology; How to Choose a Sampling Technique for Research. SSRN Electronic Journal, January 2016.

Tală, M. L., \& Pădurean, A. M. (2008). Dimensions of religious tourism. Amfiteatru Economic, 10(SUPPL. 2), 242-253.

Tall, D., \& Vinner, S. (1981). Concept Image and Concept Definition in Mathematics with Particular Reference to Limits and Continuity. Educational Studies in Mathematics, 12.

Tan, W. K. (2017). Repeat visitation: A study from the perspective of leisure constraint, tourist experience, destination images, and experiential familiarity. In Journal of Destination Marketing and Management (Vol. 6, Issue 3, pp. 233-242).

Tasci, A. D. A., Gartner, W. C., \& Tamer Cavusgil, S. (2007). Conceptualization and Operationalization of Destination Image. Journal of Hospitality and Tourism Research, 31(2), 194-223.

Tavitiyaman, P., Qu, H., Tsang, W. sze L., \& Lam, C. wah R. (2021). The influence of smart tourism applications on perceived destination image and behavioral intention: The moderating role of information search behavior. In Journal of Hospitality and Tourism Management (Vol. 46, pp. 476-487).

Toudert, D., \& Bringas-Rábago, N. L. (2019). Destination food image, satisfaction and outcomes in a border context: tourists vs excursionists. British Food Journal, 121(5), 1101-1115.

Trépanier, M., Tranchant, N., \& Chapleau, R. (2007). Individual trip destination estimation in a transit smart card automated fare collection system. Journal of Intelligent Transportation Systems: Technology, Planning, and Operations, 11(1), 1-14.

Tucker, M., Jubb, C., \& Yap, C. J. (2019). The theory of planned behaviour and student banking in Australia. International Journal of Bank Marketing, 38(1), 113-137.

Tukamushaba, E. K. ., Xiao, H., \& Ladkin, A. (2016). The effect of tourists' perceptions of a tourism product on memorable travel experience: Implications for destination branding. European Journal of Tourism, Hospitality and Recreation, 7(1), 2-12.

Viet, B. N., Dang, H. P., \& Nguyen, H. H. (2020). Revisit intention and satisfaction: The role of destination image, perceived risk, and cultural contact. Cogent Business \& Management, 7(1).

Wang, C. Y., \& Hsu, M. K. (2010). The relationships of destination image, satisfaction, and behavioral intentions: An integrated model. Journal of Travel and Tourism Marketing, 27(8), 829-843.

Wang, Y. (2016). More important than ever: Measuring Tourist Satisfaction. In Griffith Institute for Tourism Research (Issue 10).

Yoon, Y., \& Uysal, M. (2005). An examination of the effects of motivation and satisfaction on destination loyalty: A structural model. Tourism Management, 26(1), 45-56.

Zeithaml, V. A., Leonard L. Berry, \& Parasurama, A. (1996). The Behavioral Consequences of Service Quality. Contributions to Management Science, 60(2), 31-46.

Zemła, M. (2016). Tourism destination: The networking approach. Moravian Geographical Reports, 24(4), 2-14.

http://www.tatoli.tl/2018/06/08/fulan-neen-deit-vizitante-ramelau$\underline{31-235 /}$

\section{Appendix A. The Research Instruments}

\section{Tourism Destination Image}

\begin{tabular}{ll} 
Code & Item \\
\hline DI1 & Natural Attractions \\
DI1 & $\begin{array}{l}\text { The Ramelau mountain is a cultural and historical tourism } \\
\text { destination with its astonishing natural scenery. } \\
\text { The Ramelau mountain as a tourism destination has a } \\
\text { beautiful and small water stream. }\end{array}$ \\
DI13 & The Ramelau Mountain has a spectacular view. \\
DI14 & $\begin{array}{l}\text { Ramelau Mountain has diversification of Flora and Fauna } \\
\text { (wild animals). }\end{array}$ \\
DI2 & Cultural attractions \\
DI21 & $\begin{array}{l}\text { The Ramelau mountain is a fascinating cultural and } \\
\text { patrimonial tourism destination }\end{array}$ \\
DI22 & $\begin{array}{l}\text { The chapel and statue of our Lady are well-known } \\
\text { construction which is representing the characteristic } \\
\text { uniqueness of Ramelau Mountain. }\end{array}$ \\
DI23 & $\begin{array}{l}\text { The Ramelau mountain is an interesting historical } \\
\text { destination. }\end{array}$ \\
DI24 & $\begin{array}{l}\text { There is a unique custom life and tradition in Ramelau } \\
\text { Mountain. }\end{array}$ \\
\hline DI25 & $\begin{array}{l}\text { In Ramelau Mountain, there are available delicious } \\
\text { traditional foods }\end{array}$ \\
\hline
\end{tabular}




\begin{tabular}{|c|c|}
\hline DI26 & $\begin{array}{l}\text { The Ramelau Mountain has local products which can } \\
\text { represent and promote local culture. }\end{array}$ \\
\hline DI3 & Social and environmental adjustment \\
\hline DI31 & It is secure to travel to the Ramelau Mountain. \\
\hline DI32 & $\begin{array}{l}\text { The Ramelau Mountain has the virtuous and clean } \\
\text { environment. }\end{array}$ \\
\hline DI33 & Local people have great hospitality. \\
\hline DI34 & Ramelau Mountain has friendly climate. \\
\hline DI35 & $\begin{array}{l}\text { Ramelau Mountain has silent and peaceful location to spend } \\
\text { a day visit. }\end{array}$ \\
\hline DI4 & Infrastructures and facilities \\
\hline DI41 & $\begin{array}{l}\text { The Ramelau Mountain has high quality of infrastructures } \\
\text { such as road, water, electricity, beautiful landscape, and etc. }\end{array}$ \\
\hline DI42 & $\begin{array}{l}\text { The Ramelau Mountain has available various quality of } \\
\text { accommodation. }\end{array}$ \\
\hline DI43 & $\begin{array}{l}\text { The Ramelau Mountain has different types of market } \\
\text { facilities and products. }\end{array}$ \\
\hline DI44 & $\begin{array}{l}\text { It is an opportunity to explore the Ramelau mountain using } \\
\text { motorcycles adventure, climbing, tracking, camping, picnic, } \\
\text { and etc. }\end{array}$ \\
\hline DI5 & Accessibility \\
\hline DI51 & $\begin{array}{l}\text { It is available an well organize sign and information board at } \\
\text { the parking site. }\end{array}$ \\
\hline DI52 & The Ramelau Mountain has good parking site. \\
\hline DI53 & $\begin{array}{l}\text { The Ramelau Mountain has good and convenient access to } \\
\text { the nearby cities i.e. Maubisse, Aileu, Ainaro and Same } \\
\text { and Dili. }\end{array}$ \\
\hline DI54 & $\begin{array}{l}\text { The Ramelau Mountain has good and convenience public } \\
\text { transportation. }\end{array}$ \\
\hline DI6 & Price and Value \\
\hline DI61 & $\begin{array}{l}\text { The visiting price of the Ramelau Mountain is cheaper than } \\
\text { any other tourist destinations in Timor-Leste }\end{array}$ \\
\hline DI62 & $\begin{array}{l}\text { In the Ramelau Mountain, foods and accommodations have } \\
\text { reasonable price. }\end{array}$ \\
\hline DI63 & In Ramelau Mountain, local products have reasonable price. \\
\hline
\end{tabular}

\section{Tourist Satisfaction}

\begin{tabular}{ll}
\hline Code & \multicolumn{1}{c}{ Item } \\
TS1 & I am very happy with my trip to the Ramelau Mountain. \\
TS2 & My preference to choose the Ramelau mountain is prudent \\
TS3 & $\begin{array}{l}\text { My experience to the Ramelau Mountain meets my } \\
\text { expectation }\end{array}$ \\
TS4 & $\begin{array}{l}\text { I am satisfy with my personal decision to visit the Ramelau } \\
\text { Mountain }\end{array}$ \\
TS5 & $\begin{array}{l}\text { I am satisfied with the quality of service available from the } \\
\text { accommodation at the Ramelau Mountain. }\end{array}$ \\
TS6 & $\begin{array}{l}\text { It is my best commitment I have done personally to visiting } \\
\text { the Ramelau Mountain. }\end{array}$ \\
\hline
\end{tabular}

\section{Behavioral Intention}

\begin{tabular}{ll}
\hline Code & Item \\
\hline & $\begin{array}{l}\text { I will inform my relatives and friends about my admiration } \\
\text { about the Ramelau mountain and I stay longer than actual } \\
\text { plan. }\end{array}$ \\
\hline
\end{tabular}

\begin{tabular}{ll}
\hline BI2 & $\begin{array}{l}\text { I will share my experience of visiting the Ramelau mountain } \\
\text { to friends and family. }\end{array}$ \\
BI3 & $\begin{array}{l}\text { I would like to come back to visit the Ramelau mountain with } \\
\text { friends and relatives. }\end{array}$ \\
BI4 & $\begin{array}{l}\text { I would like to revisit the Ramelau mountain in a next couple } \\
\text { of years. }\end{array}$ \\
BI5 & $\begin{array}{l}\text { I will recommend the trip to Ramelau mountain to family and } \\
\text { friends more than any other tourism destinations in Timor- } \\
\text { Leste. }\end{array}$ \\
BI6 & $\begin{array}{l}\text { I will recommend the Ramelau mountain to other potential } \\
\text { visitors. }\end{array}$ \\
\hline
\end{tabular}

